University of Nebraska - Lincoln

DigitalCommons@University of Nebraska - Lincoln

\title{
Simulating Nitrate Drainage Losses from a Walnut Creek Watershed Field
}

\author{
A. Bakhsh \\ lowa State University \\ J. L. Hatfield \\ USDA-ARS, jerry.hatfield@ars.usda.gov
}

R. S. Kanwar

lowa State University, rskanwar@iastate.edu

L. Ma

USDA-ARS

L. R. Ahuja

USDA-ARS

Follow this and additional works at: https://digitalcommons.unl.edu/usdaarsfacpub

Bakhsh, A.; Hatfield, J. L.; Kanwar, R. S.; Ma, L.; and Ahuja, L. R., "Simulating Nitrate Drainage Losses from a Walnut Creek Watershed Field" (2004). Publications from USDA-ARS / UNL Faculty. 1370.

https://digitalcommons.unl.edu/usdaarsfacpub/1370

This Article is brought to you for free and open access by the U.S. Department of Agriculture: Agricultural Research Service, Lincoln, Nebraska at DigitalCommons@University of Nebraska - Lincoln. It has been accepted for inclusion in Publications from USDA-ARS / UNL Faculty by an authorized administrator of DigitalCommons@University of Nebraska - Lincoln. 


\title{
Ground Water Quality
}

\section{Simulating Nitrate Drainage Losses from a Walnut Creek Watershed Field}

\author{
A. Bakhsh, J. L. Hatfield, R. S. Kanwar,* L. Ma, and L. R. Ahuja
}

\begin{abstract}
This study was designed to evaluate the improved version of the Root Zone Water Quality Model (RZWQM) using 6 yr (1992-1997) of field-measured data from a field within Walnut Creek watershed located in central Iowa. Measured data included subsurface drainage flows, $\mathrm{NO}_{3}-\mathrm{N}$ concentrations and loads in subsurface drainage water, and corn (Zea mays L.) and soybean [Glycine $\max ($ L.) Merr.] yields. The dominant soil within this field was Webster (fine-loamy, mixed, superactive, mesic Typic Endoaquolls) and cropping system was cornsoybean rotation. The model was calibrated with 1992 data and was validated with 1993 to 1997 data. Simulations of subsurface drainage flow closely matched observed data showing model efficiency of $99 \%$ $(E F=0.99)$, and difference $(D)$ of $1 \%$ between measured and predicted data. The model simulated $\mathrm{NO}_{3}-\mathrm{N}$ losses with subsurface drainage water reasonably well with $\mathrm{EF}=0.8$ and $D=13 \%$. The simulated corn grain yields were in close agreement with measured data with $D<\mathbf{1 0} \%$. Nitrogen-scenario simulations demonstrated that corn yield response function reached a plateau when $\mathrm{N}$-application rate exceeded $90 \mathrm{~kg} \mathrm{ha}^{-1}$. Fraction of applied $\mathrm{N}$ lost with subsurface drainage water varied from 7 to $16 \%$ when $\mathrm{N}$-application rate varied from 30 to $180 \mathrm{~kg} \mathrm{ha}^{-1}$ after accounting for the nitrate loss with no-fertilizer application. These results indicate that the RZWQM has the potential to simulate the impact of $\mathrm{N}$ application rates on corn yields and $\mathrm{NO}_{3}-\mathrm{N}$ losses with subsurface drainage flows for agricultural fields in central Iowa.
\end{abstract}

$\mathrm{A}^{\mathrm{p}}$ Plication of $\mathrm{N}$ to agricultural lands is essential for sustaining food and fiber production. The agriculture sector, however, has been recognized as the single largest contributor to non-point-source nitrate pollution of surface and groundwater bodies in the Midwestern United States (Hatfield et al., 1999; Jaynes et al., 1999; Kanwar et al., 1999; Rejesus and Hornbaker, 1999). Poorly drained soils of the Midwest need subsurface drainage systems to achieve their productivity levels. The subsurface drainage system not only removes excess water from the root zone but also transports soluble nitrates from the bottom of the root zone to the edge of the field (Hatfield et al., 1998). Subsurface drainage water often contains significant amounts of $\mathrm{NO}_{3}-\mathrm{N}$, which are then transported to surface water bodies including lakes, streams, and rivers. Elevated $\mathrm{NO}_{3}-\mathrm{N}$ con-

A. Bakhsh and R.S. Kanwar, Dep. of Agricultural and Biosystems Engineering, Iowa State Univ.; J.L. Hatfield, USDA-ARS, National Soil Tilth Laboratory, Ames, IA 50011; L. Ma and L.R. Ahuja, USDAARS, Great Plains System Research Unit, Fort Collins, CO 80522. Journal Paper no. J-19322 of the Iowa Agriculture and Home Economics Exp. Stn., Ames, IA, Project no. 3145. Received 5 July 2002. *Corresponding author (rskanwar@iastate.edu).

Published in J. Environ. Qual. 33:114-123 (2004).

(c) ASA, CSSA, SSSA

677 S. Segoe Rd., Madison, WI 53711 USA centrations in the Mississippi River have been associated with the extensive drainage system in the upper Midwest (Randall and Mulla, 2001). Therefore, monitoring and evaluation of subsurface drainage water quality is important to reduce $\mathrm{NO}_{3}-\mathrm{N}$ leaching losses and promote the use of sustainable farming practices (Kanwar et al., 1998).

Computer simulation models offer efficient and costeffective alternatives to field experiments for evaluating the impact of different farming practices on soil and water quality (Bakhsh et al., 2000a; Knisel and Turtola, 2000). The RZWQM incorporates the state-of-the-science knowledge of agricultural systems into a tool for agricultural research and management, environmental assessment, and technology transfer (Ma et al., 2000). The RZWQM is a one-dimensional (vertical soil profile) field-scale model. It integrates physical, chemical, and biological processes to simulate plant growth, water, nutrients, and pesticide movement within the soil profile for a representative point in the field. The model uses the Green-Ampt equation to simulate infiltration and the one-dimensional Richard's equation to redistribute water within the soil profile. The model uses the modified Brooks-Corey equations to numerically represent the soil moisture and hydraulic conductivity relationships (Ahuja et al., 2000, p. 372). The nutrient submodel of the RZWQM defines the carbon and N-transformation processes within the soil profile using an interlinked multipool approach for organic matter cycling (Ma et al., 1998). The generic plant growth submodel simulates the response of plants to the environment. A detailed description of RZWQM can be found in Ahuja et al. (2000, p. 372).

An earlier version (v. 3.2) of the RZWQM was evaluated by several scientists working on the management system evaluation area (MSEA) sites using data collected from several sites from 1991 to 1994 . These studies included soil-water and pesticide components $(\mathrm{Wu}$ et al., 1999); runoff and chemical losses to runoff (Ghidey et al., 1999); plant, soil, and water parameters (Jaynes and Miller, 1999; Martin and Watts, 1999); and plant production components (Landa et al., 1999). The RZWQM has been improved since then (Ma et al., 2000), however, and more data have been collected at

\footnotetext{
Abbreviations: $A_{\mathrm{s}}$, age parameter; CRM, coefficient of residual mass; $D$, difference between predicted and observed data; DOY, day of year; DP, drainable porosity; EF, model efficiency; ET, evapotranspiration; FWANC, flow-weighted average nitrate concentrations in subsurface drainage water; MSEA, management system evaluation area; $\mathrm{N}_{\max }$, nitrogen-uptake coefficient; RMSE, root mean square error; RZWQM, Root Zone Water Quality Model with Windows interface.
} 
Table 1. Soil horizon properties of the Webster soil used as model input. $\dagger$

\begin{tabular}{|c|c|c|c|c|c|c|c|c|}
\hline \multirow[b]{2}{*}{ Horizon } & \multirow[b]{2}{*}{ Depth } & \multirow{2}{*}{$\begin{array}{c}\text { Bulk } \\
\text { density } \ddagger\end{array}$} & \multirow[b]{2}{*}{ Porosity } & \multirow{2}{*}{$\begin{array}{c}\text { Field } \\
\text { capacity } \dagger\end{array}$} & \multirow{2}{*}{$\begin{array}{c}\text { Hydraulic } \\
\text { conductivity } \dagger\end{array}$} & \multicolumn{3}{|c|}{ Soil texture } \\
\hline & & & & & & Sand & Silt & Clay \\
\hline & m & $\mathbf{M g ~ m}^{-3}$ & & & $\mathbf{m m ~ \mathbf { h } ^ { - 1 }}$ & 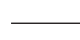 & $\%$ & 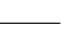 \\
\hline 1 & 0.16 & 1.20 & 0.55 & 0.28 & 35 & 25 & 42 & 33 \\
\hline 2 & 0.27 & 1.24 & 0.53 & 0.28 & 35 & 24 & 40 & 36 \\
\hline 3 & 0.66 & 1.30 & 0.51 & 0.28 & 35 & 26 & 39 & 35 \\
\hline 4 & 0.92 & 1.32 & 0.50 & 0.27 & 35 & 26 & 40 & 34 \\
\hline 5 & 1.12 & 1.41 & 0.47 & 0.24 & 35 & 26 & 41 & 33 \\
\hline 6 & 1.48 & 1.65 & 0.38 & 0.13 & 35 & 44 & 36 & 20 \\
\hline 7 & 2.50 & 1.78 & $\mathbf{0 . 3 3}$ & 0.16 & 6 & 39 & 42 & 19 \\
\hline 8 & 2.94 & 1.78 & $\mathbf{0 . 3 3}$ & 0.14 & 6 & 52 & 32 & 16 \\
\hline
\end{tabular}

F Adjustments were made during calibration.

+ USDA (1994).

the MSEA sites. Therefore, this study was designed to evaluate the latest improved version of the RZWQM (Ahuja et al., 2000, p. 372) using one of the MSEA sites in Iowa with the following objectives: (i) Calibrate and validate the RZWQM to simulate subsurface drain flows and $\mathrm{NO}_{3}-\mathrm{N}$ losses in subsurface drainage water beneath corn-soybean rotation system using 6 yr (1992 to 1997) of field-measured data for a field within Walnut Creek watershed; (ii) simulate $\mathrm{NO}_{3}-\mathrm{N}$ leaching potential with subsurface drainage flow under different $\mathrm{N}$-application rates; and (iii) estimate the fraction of applied $\mathrm{N}$ lost with subsurface drainage water based on different $\mathrm{N}$-scenario simulations.

\section{MATERIALS AND METHODS Site Description}

Walnut Creek watershed is a 5130-ha watershed located on the Des Moines Lobe landform region just south of Ames, IA, $41^{\circ} 55^{\prime}$ to $42^{\circ} 00^{\prime} \mathrm{N}$ and $93^{\circ} 32^{\prime}$ to $93^{\circ} 45^{\prime} \mathrm{W}$. This intensively farmed area of central Iowa, located in Major Land Resource Area 103 and the Western Corn Belt Plains Ecoregion, is highly suited to row crop production. This watershed was one of the sites in the MSEA program (Hatfield et al., 1999).

A 44.5-ha field from within the Walnut Creek watershed was selected for this simulation study because it has been intensively monitored from 1992 to 1997 . This field is comprised of Canisteo (fine-loamy, mixed, superactive, calcareous, mesic Typic Endoaquolls), Clarion (fine-loamy, mixed, superactive, mesic Typic Hapludolls), Harps (fine-loamy, mixed, superactive, mesic Typic Calciaquolls), Nicollet (fine-loamy, mixed, superactive, mesic, Aquic Hapludolls), Okoboji (fine, smectitic, mesic Cumulic Vertic Endoaquolls), and Webster soils, with a major portion $(34 \%)$ of Webster soil in the field. Soil physical properties of Webster soil were used in the model (Table 1). The field had been under a long-term corn-soybean rotation with chisel plowing in the fall after corn harvest and spring cultivation before planting and field cultivation during the growing season to control weeds. Corn was planted in 750-mm rows in 1993, 1995, and 1997. Soybean was planted in 350-mm rows in 1992, 1994, and 1996. Nitrogen fertilizer at the rate of $90 \mathrm{~kg} \mathrm{ha}^{-1}$ was applied to corn as $\mathrm{NH}_{3}$ injected 1 wk before planting, and no $\mathrm{N}$ fertilizer was applied to soybean (Table 2). The field was owned, managed, and operated by a farmer-cooperator in the MSEA program (Hatfield et al., 1999).

The field was drained by a single subsurface drain installed at approximately $1.2-\mathrm{m}$ depth below the ground surface. Monitoring subsurface drainage flow setup included a FLO-TOTE system (Marsh-McBirney, Frederick, MD) ${ }^{1}$ for measuring flow within the pipe to collect and record the data. Water samples were collected for nitrate analysis with a sampler (Model 3700; ISCO, Lincoln, NE) programmed to collect water samples based on volume of water discharged. These units were checked weekly for proper operation and correct performance. Nitrate concentrations in the water samples were analyzed following the procedure described by Hatfield et al. (1999).

\section{Model Input Data}

Meteorological data measured on-site were comprised of daily minimum and maximum temperatures, hourly wind speed, solar radiation, and actual and saturated vapor pressure (relative humidity). Daily values were used in the model input files. Hourly rainfall data, available from a tipping-bucket apparatus, were used to prepare the breakpoint input file. The procedures for these measurements are explained in Hatfield et al. (1999).

The RZWQM requires input of soil physical properties for sand, silt, and clay fractions, bulk density, and 0.03-MPa field capacity values for each discrete soil horizon of the specified soil profile (Table 1). These data were available from measurements made by the USDA (1994) from a soil profile within the watershed. Management data for tillage, planting, and fertilizer operations were required as model input (Table 2).

The initial values for soil water content, soil temperature, crop residue, organic matter, and microbial $\mathrm{N}$ pools were obtained from a nearby site study (Bakhsh et al., 2001). Both these sites have been under similar management (cornsoybean rotation) and climate, and were operated by the farmers. These initial values, however, were tested against the steady state values obtained following the approach of Ma et al. (1998), and no difference was observed. Further details of this approach can be found in Ma et al. (1998) and Bakhsh et

\footnotetext{
${ }^{1}$ Use of trade names is for reader information and does not imply any endorsement by USDA-ARS or Iowa State University.
}

Table 2. Management operations for the study field.

\begin{tabular}{|c|c|c|c|c|}
\hline Year & Crop & Planting date & Harvesting date & Fertilizer $\dagger$ \\
\hline & & & & $\mathrm{kg} \mathrm{ha}^{-1}$ \\
\hline 1992 & soybean & 15 May & 15 Oct. & $\mathbf{0}$ \\
\hline 1993 & corn & 1 May & 30 Oct. & 90 \\
\hline 1994 & soybean & 1 May & 25 Oct. & 0 \\
\hline 1995 & corn & 15 May & 20 Oct. & 90 \\
\hline 1996 & soybean & 15 May & 25 Oct. & 0 \\
\hline 1997 & corn & 5 May & 1 Nov. & 90 \\
\hline
\end{tabular}

$\uparrow \mathrm{NH}_{3}$ injected by spoke injector $1 \mathrm{wk}$ before planting, chisel plow in fall $1 \mathrm{wk}$ after corn harvest, field cultivation $1 \mathrm{wk}$ before planting, 3-wk postemergence for weed control. 
al. (2001). Drainage information was set equal to the average subsurface drain depth of $1.2 \mathrm{~m}$, drain radius of $100 \mathrm{~mm}$, and drain spacing of $33 \mathrm{~m}$. The option of constant flux (only with water table), available in the model, was used as the bottom boundary condition.

\section{Model Calibration}

The model was calibrated for the hydrologic, nutrient, and plant growth components sequentially. During hydrologic calibration, the subsurface drainage flow simulations were compared with measured data and the corresponding parameters were adjusted as described by Hanson et al. (1999). Drainable porosity (DP; difference between porosity and field capacity) and hydraulic conductivity were the key parameters in adjusting the subsurface drainage flow (Shirmohammadi et al., 1998; Bakhsh et al., 2001). The 1992 year was selected for calibration of the hydrologic component because it had annual precipitation of $801 \mathrm{~mm}$, close to the normal annual precipitation of $818 \mathrm{~mm}$ for this area (Hatfield et al., 1999) and because 1992 began the simulation sequence. In addition to statistical measures used for model validation based on 5 yr (1993-1997) data, the calibration criteria also focused on minimizing the difference between measured and simulated subsurface drainage flow data and matching peaks of the observed and simulated drain flow hydrographs.

The calibration of the nutrient component for 1992 was a critical process because of several soil, plant, climate, and management parameter effects on $\mathrm{N}$-transformation processes and a lack of observed data for various processes (e.g., mineralization, nitrification, and denitrification rates) for the study field. The approach suggested by Hanson et al. (1999) and Ma et al. (1998) was used to calibrate the nutrient submodel. The initial N-pool values, however, are very important for adequate simulations of nitrate leaching losses with subsurface drainage flows. The nitrate leaching losses with subsurface drainage flows were affected by adjusting the plant $\mathrm{N}$-uptake parameter, which also affected the crop yield predictions.

Plant growth components of the model were initialized using plant parameters recommended for Iowa conditions (Hanson et al., 1999). The measured crop yield data for this particular field were not available because it was managed by the farmer. The corn grain yield data, however, for another field within Walnut Creek watershed reported by Jaynes and Miller (1999), a nearby field by Bakhsh et al. (2001), and for Iowa conditions by Hanson et al. (1999) were utilized during the calibration of the plant component. The age parameters $\left(A_{\mathrm{s}}\right)$ were adjusted to control crop yield predictions while maintaining the recommended limits of harvest index (ratio of yield from seeds to total biomass above the ground) between 52 to $55 \%$ (Hanson et al., 1999). Corn grain yield for 1993 was calibrated by adjusting the nitrogen-uptake coefficient $\left(\mathrm{N}_{\max }\right)$ and $A_{\mathrm{s}}$, while the other regional parameters (Table 3 ) were

Table 3. List of crop-specific calibration parameters.

\begin{tabular}{|c|c|c|}
\hline Parameters & Corn & Soybean \\
\hline Maximum $N$-uptake rate $\left(\mathrm{N}_{\text {max }}\right), \mathrm{g}_{\text {plant }}{ }^{-1} \mathrm{~d}^{-1} \dagger$ & 2.90 & 0.50 \\
\hline Proportion of photosynthesis to respiration $\dagger$ & 0.15 & 0.005 \\
\hline $\begin{array}{l}\text { Amount of biomass needed to obtain leaf area } \\
\text { index of } 1.0, g_{\dagger}^{\dagger}\end{array}$ & 10.00 & 1.50 \\
\hline Plant density, plants ha ${ }^{-1} \ddagger$ & 66295 & 441035 \\
\hline $\begin{array}{l}\text { Age effect for propagules as proportion } \\
\text { of photosynthesis } \dagger\end{array}$ & 0.90 & 0.25 \\
\hline $\begin{array}{l}\text { Age effect for seed as proportion of } \\
\text { photosynthesis }\left(A_{\mathrm{s}}\right) \dagger\end{array}$ & 0.47 & 0.30 \\
\hline Normal maximum root system depth, m & 1.20 & 1.00 \\
\hline
\end{tabular}

$\dagger$ Regional plant parameters. $\mathbf{N}_{\max }$, nitrogen-uptake coefficient; $\boldsymbol{A}_{\mathrm{s}}$, age parameter.

† From Jaynes and Miller (1999). left unchanged because of a lack of measured data on plant biomass. After calibration, the 6-yr model simulations were made with a single run from 1 Jan. 1992 through 31 Dec. 1997. These continuous simulations were made to avoid any further initialization process for the subsequent years.

\section{Model Evaluation Criteria}

Several model performance indicators were used to judge the model prediction capability, including the following.

\section{Percentage of Difference}

The MSEA model applications team required simulated yield estimates to match the model predictions and observed attributes within 15\% (Hanson et al., 1999). The goodness of fit statistic was $\% D$, the percentage of difference between the predicted $\left(P_{\mathrm{i}}\right)$ and observed $\left(O_{\mathrm{i}}\right)$ indicator variables (Ahuja et al., 2000, p. 372).

$$
\% D=\left(P_{\mathrm{i}}-O_{\mathrm{i}}\right) / O_{\mathrm{i}} \times 100
$$

Loague and Corwin (1996) suggested that a model's performance is judged acceptable if it is not possible to reject the hypothesis of no difference between observed and predicted values. The standard way of validating a model, however, would be to apply certain tests to assess the goodness of fit of the model predictions. Loague and Green (1991) and Vinten et al. (1991) applied the following four measures to judge the model's prediction capability.

\section{Root Mean Square Error}

The value of root mean square error (RMSE) should be equal to zero for a model showing perfect fit between the observed and predicted data:

$$
\operatorname{RMSE}=\frac{\left[\sum_{i=1}^{n}\left(P_{\mathrm{i}}-O_{\mathrm{i}}\right)^{2} / n\right]^{0.5}}{\bar{O}} \times 100
$$

\section{Coefficient of Determination}

This measure shows proportion of the total variance explained by the model and its value is 1.0 for a perfect fit between the observed and predicted data:

$$
R^{2}=\frac{\sum_{i=1}^{n}\left(O_{\mathrm{i}}-\bar{O}\right)^{2}}{\sum_{i=1}^{n}\left(P_{\mathrm{i}}-\bar{O}\right)^{2}}
$$

\section{Model Efficiency}

The EF is a measure of the deviation between model predictions and measurements relative to the scattering of the observed data (Wu et al., 1999). The EF is calculated using the Nash and Sutcliffe (1970) relationship and its value is 1.0 for a perfect fit:

$$
\mathrm{EF}=1-\frac{\sum_{i=1}^{n}\left(P_{\mathrm{i}}-O_{\mathrm{i}}\right)^{2}}{\sum_{i=1}^{n}\left(O_{\mathrm{i}}-\bar{O}\right)^{2}}
$$

\section{Coefficient of Residual Mass}

This indicator shows the difference in observed and predicted data relative to the observed data and is similar to the percentage difference discussed above when multiplied by 100 : 


$$
\mathrm{CRM}=\frac{\left(\sum_{i=1}^{n} O_{\mathrm{i}}-\sum_{i=1}^{n} P_{\mathrm{i}}\right)}{\sum_{i=1}^{n} O_{\mathrm{i}}}
$$

where $P_{\mathrm{i}}$ and $O_{\mathrm{i}}$ are the predicted and observed values, respectively, $\bar{O}$ is the average of the observed data, and $i$ is the number of observations ranging from 1 to $n$.

\section{RESULTS AND DISCUSSION}

\section{Model Calibration and Parameterization Results}

On the basis of an available soil property data set, the soil horizon was discretized using soil texture information for the entire soil profile (Table 1). A deep soil profile of $2.94 \mathrm{~m}$ was used so that the simulated water table fluctuations would remain in the soil horizons especially during the dry year of 1994 . The study period experienced variability in precipitation ranging from a wet year in $1993(1290 \mathrm{~mm})$ to a dry year in 1994 (560 $\mathrm{mm})$ and near average precipitation in $1992(800 \mathrm{~mm})$, 1995 (723 mm), 1996 (895 mm), and 1997 (671 mm).

Calibration of the hydrologic component of the model using measured subsurface drainage flow data revealed that DP and hydraulic conductivity were the key parameters in adjusting the simulated subsurface drainage flow hydrograph (Shirmohammadi et al., 1998; Bakhsh et al., 2001). The adjustment of DP values during calibration of subsurface drainage flow accounted for effects of spatial variability of soil properties and enabled a single soil profile to represent the actual complex field conditions (Bakhsh et al., 2000b; Knisel and Turtola, 2000; Ma et al., 2000). The DP value for a certain horizon controlled water movement for that particular horizon. The DP of the top layer was critical because it affected subsurface drainage and evapotranspiration (ET) rates. When drainage was limited by DP, soil evaporation was greater than expected. The DP was varied from 0.27 to 0.19 from the top horizon to the bottom. Adjustment of DP values and the initial soil moisture contents helped bring the predicted subsurface drainage flow of 1992 (calibration year) closer to the measured data (Fig. 1).

During calibration of the hydrologic module, care was taken to predict the ET values within acceptable ranges for the study area and to obtain a good agreement between simulated and measured subsurface drainage flow data. The model underpredicted ET by $21 \%$ (387 vs. $493 \mathrm{~mm}$ ) for the 1992 growing season (7 May-16 October), and 18\% (383 vs. $467 \mathrm{~mm}$ ) for the 1993 growing season (10 June-7 October). The ET was predicted closely with a difference of $2 \%$ (326 vs. $334 \mathrm{~mm}$ ) for the 1994 growing season (15 June to 23 September). Measured ET data for 1995, 1996, and 1997 were not available for this field. Similar results of model predictions of ET have been reported by Jaynes and Miller (1999) in another Walnut Creek watershed field. The purpose of comparing ET simulations with measured data was to consider ET as one of the soil water balance parameters in addition to drainage because no runoff was observed for this field.
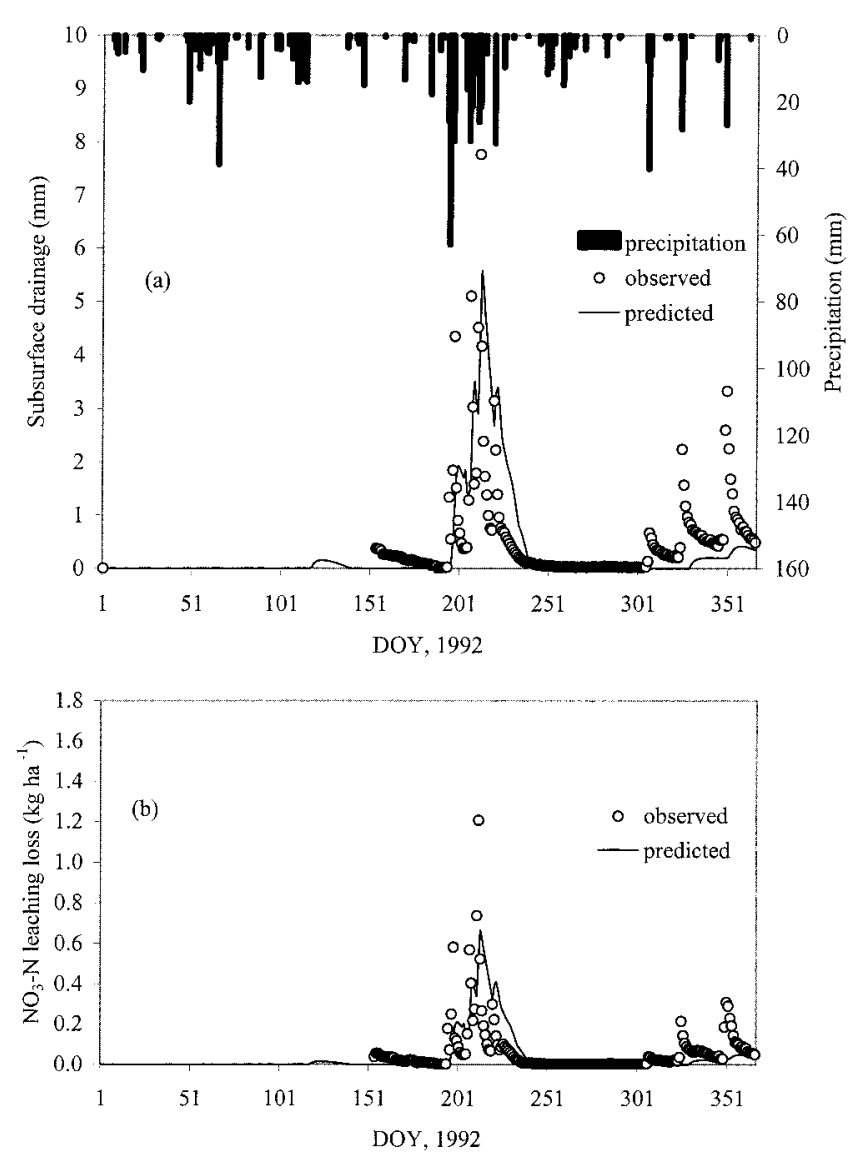

Fig. 1. Root Zone Water Quality Model with Windows interface simulations for $(a)$ subsurface drainage and $(b) \mathrm{NO}_{3}-\mathrm{N}$ losses in subsurface drainage water in relation to rainfall for 1992. DOY, day of year.

Calibration of the nutrient and plant components was interrelated because adjustment of one parameter such as $\mathrm{N}_{\max }$ affected both nitrate leaching loss and crop yield predictions. Therefore, simulation of only nitrate drainage losses without including the plant component may introduce error in the calibration parameters.

\section{Nitrate Leaching Losses with Subsurface Drainage Water}

Observed annual subsurface drainage flows were sensitive to the annual amount of precipitation. The maximum drainage volume of $606 \mathrm{~mm}$ was observed in 1993, which had an annual precipitation of $1290 \mathrm{~mm}(58 \%>$ normal). The minimum drainage effluent was $68 \mathrm{~mm}$ in 1994, which had an annual precipitation of $560 \mathrm{~mm}$ $(32 \%<$ normal). Simulated subsurface drainage flow agreed with the measured data trend. The overall difference between measured and predicted subsurface drainage flow, when averaged across validation years (19931997), was <5\% (225 vs. $223 \mathrm{~mm}$ ) (Table 4). Similarly, model evaluation based on various indicators of RMSE $(=6.7 \%), R^{2}(=1.1), \mathrm{EF}(=0.99)$, and coefficient of residual mass $(\mathrm{CRM}=0.0)$, was found to be satisfactory (Table 4). A EF value close to 1.0 indicates a good match between observed and simulated subsurface drainage (Saleh et al., 2000). Temporal evaluation of the model 
Table 4. Root Zone Water Quality Model with Windows interface simulation results from 1992 to 1997 with various model performance indicators. $\dagger$

\begin{tabular}{|c|c|c|c|c|c|c|c|c|c|c|c|c|}
\hline \multirow[b]{2}{*}{ Variables } & \multicolumn{6}{|c|}{ Years } & \multicolumn{6}{|c|}{ For validation years $(1993-1997)+$} \\
\hline & 1992 & 1993 & 1994 & 1995 & 1996 & 1997 & Mean & $\boldsymbol{D}$ & RMSE & $R^{2}$ & $\mathbf{E F}$ & CRM \\
\hline & \multicolumn{7}{|c|}{ Annual precipitation } & $\%$ & - & & & \\
\hline & & & 560 & $\frac{\mathrm{mm}}{723}$ & & & 823 & & & & & \\
\hline Precipitation & \multicolumn{7}{|c|}{$\underline{\text { Subsurface drainage }}$} & & & & & \\
\hline \multirow{3}{*}{$\begin{array}{l}\text { Observed } \\
\text { Predicted }\end{array}$} & $\begin{array}{l}117.0 \\
110.6\end{array}$ & $\begin{array}{l}606.3 \\
592.3\end{array}$ & $\begin{array}{l}67.8 \\
59.5\end{array}$ & $\begin{array}{r}-\mathrm{mm} \\
124.7 \\
152.6\end{array}$ & $\begin{array}{l}207.1 \\
207.3\end{array}$ & $\begin{array}{l}106.6 \\
114.8\end{array}$ & $\begin{array}{l}222.5 \\
225.3\end{array}$ & 1.2 & 6.7 & 1.1 & 0.99 & 0.0 \\
\hline & \multicolumn{7}{|c|}{$\mathrm{NO}_{3}-\mathrm{N}$ loss via subsurface drainage flow§ } & & & & & \\
\hline & & & & kg N ha & & & & & & & & \\
\hline Observed & 13.3 & 63.1 & 5.1 & 11.6 & 22.7 & 11.7 & 22.8 & & & & & \\
\hline \multirow[t]{3}{*}{ Predicted } & 12.9 & 85.1 & 5.7 & 11.9 & 18.2 & 8.0 & 25.8 & 12.9 & 44.5 & 0.5 & 0.8 & -0.1 \\
\hline & \multirow{2}{*}{\multicolumn{7}{|c|}{$\frac{\text { FWANCII }}{\mathrm{mg} \mathrm{L}^{-1}}$}} & & & & & \\
\hline & & & & & & & & & & & & \\
\hline Observed & 11.4 & 10.4 & 7.5 & 9.3 & 10.9 & 11.0 & 9.8 & & & & & \\
\hline \multirow[t]{3}{*}{ Predicted } & 11.7 & 14.4 & 9.6 & 7.8 & 8.8 & 7.0 & 9.5 & -3.2 & 29.9 & 0.3 & -3.8 & 0.0 \\
\hline & \multirow{2}{*}{\multicolumn{7}{|c|}{$\frac{\text { Predicted crop grain yields } §}{\mathrm{~kg} \mathrm{ha}^{-1}}$}} & & & & & \\
\hline & & & & & & & & & & & & \\
\hline Corn\# & $-\overline{6}$ & 8770 & - & 8769 & - & 10125 & 9447 & 4.6 & & & & \\
\hline Soybean\# & 1660 & - & 3098 & - & 2681 & - & 2889 & 3.8 & - & - & - & - \\
\hline
\end{tabular}

$\dagger$ Measured corn grain yield (kg ha $\left.{ }^{-1}\right)=9578$ (Hanson et al., 1999); 8468 (Bakhsh et al., 2001); 8400 (Jaynes and Miller, 1999$)$. Measured soybean grain yield $\left(\mathrm{kg} \mathrm{ha}^{-1}\right)=3195$ (Bakhsh et al., 2001); 1580 (Jaynes and Miller, 1999). Average measured corn grain yield $=8815 \mathrm{~kg} \mathrm{ha}^{-1}$; Average measured soybean grain yield $=2388 \mathrm{~kg} \mathrm{ha}^{-1}$.

$+D=$ difference between predicted and observed data; $\mathbf{R M S E}=$ root mean square error; $\mathbf{E F}=$ model efficiency; CRM $=$ coefficient of residual mass. $\S$ At $90 \mathrm{~kg} \mathrm{ha}^{-1}$ fertilizer applied to corn.

II FWANC, flow-weighted average nitrate concentrations in subsurface drainage water.

\# Observed crop yield data were used from nearby fields.

response on a yearly basis was also compared by plotting the daily observed and predicted data of subsurface drainage and $\mathrm{NO}_{3}-\mathrm{N}$ losses in subsurface drainage water for all 6 yr (Fig. 1 to 6 ).

The model predicted $95 \%$ of the observed subsurface drainage water (111 vs. $117 \mathrm{~mm}$ ) for 1992 (calibration year) and responded very closely to rainfall events of $63 \mathrm{~mm}$ on day of year (DOY) 200. Regarding temporal evaluation, the model slightly overpredicted subsurface drainage water on DOY 120 , which was associated with higher initial soil moisture contents in the soil profile as the simulations were started from 1 Jan. 1992. This overprediction effect was overcome for all the remaining years because continuous simulations were conducted from 1 Jan. 1992 through 31 Dec. 1997. The model underpredicted subsurface drainage flow on DOY 320 (after crop harvest). The sharp rises in the observed drainage flow from 0.4 to $2.2 \mathrm{~mm}$ on DOY 324 and from 0.5 to $2.6 \mathrm{~mm}$ on DOY 349 , along with the underprediction of the model results, suggests the possibility of macropore flow processes (Fig. 1). Similar underpredictions of $\mathrm{NO}_{3}-\mathrm{N}$ leaching losses were observed after crop harvest as observed in case of subsurface drainage flow. The annual predicted $\mathrm{NO}_{3}-\mathrm{N}$ losses with subsurface drainage water for 1992, however, were in close agreement with the measured data, and the predicted values were $97 \%$ (12.9 vs. $\left.13.3 \mathrm{~kg} \mathrm{ha}^{-1}\right)$ of the observed values (Table 4).

Model simulations of subsurface drainage for 1993 followed the trend of observed data closely (Fig. 2), although some of the peaks were underestimated. Overall, the model predicted $98 \%$ of the observed subsurface drainage, and $\% D$ was $<5 \%$ (592 vs. $606 \mathrm{~mm}$ ) between the predicted and measured data (Table 4). Similarly, temporal evaluation of the model for $\mathrm{NO}_{3}-\mathrm{N}$ leaching losses with subsurface drainage flow was adequate, and the model responded to all the observed peaks (Fig. 2). Overall, the model overpredicted the annual amount of $\mathrm{NO}_{3}-\mathrm{N}$ drainage losses by $35 \%\left(85\right.$ vs. $\left.63 \mathrm{~kg} \mathrm{ha}^{-1}\right)$ in 1993. This year was very wet compared with all other years, and heavy rainfall events may have caused excessive flushing of $\mathrm{NO}_{3}-\mathrm{N}$ with subsurface drainage flow.

Rainfall before and after the growing season also caused sharp rises in subsurface drainage flow along with increased $\mathrm{NO}_{3}-\mathrm{N}$ leaching losses in subsurface drain flow (Fig. 3). The model underpredicted subsurface drain flow for 1994 because this year had the lowest rainfall among all 6 yr. Better predictions of $\mathrm{NO}_{3}-\mathrm{N}$ leaching losses in subsurface drain flow were observed for 1995 (Fig. 4), and the $\% D$ was found to be $<5 \%$ (11.9 vs. $11.6 \mathrm{~kg} \mathrm{ha}^{-1}$ ) between observed and predicted data. Subsurface drainage flows, however, were overestimated by $22 \%$ ( 153 vs. $125 \mathrm{~mm}$ ) for this year. The model output matched measured subsurface drain flow data well for 1996 and 1997 (Fig. 5 and 6), but $\mathrm{NO}_{3}-\mathrm{N}$ leaching losses were underestimated for these years (Table 4). Although the predicted volume of subsurface drainage flow for 1996 was in good agreement with the measured data, temporal predictions of subsurface drainage flow for 1996 were poor during the early part of the growing season, which could be due to less rainfall after harvest in 1995 and because the model simulated water table values deeper from the ground surface.

The overall analysis of the model simulations for sub- 

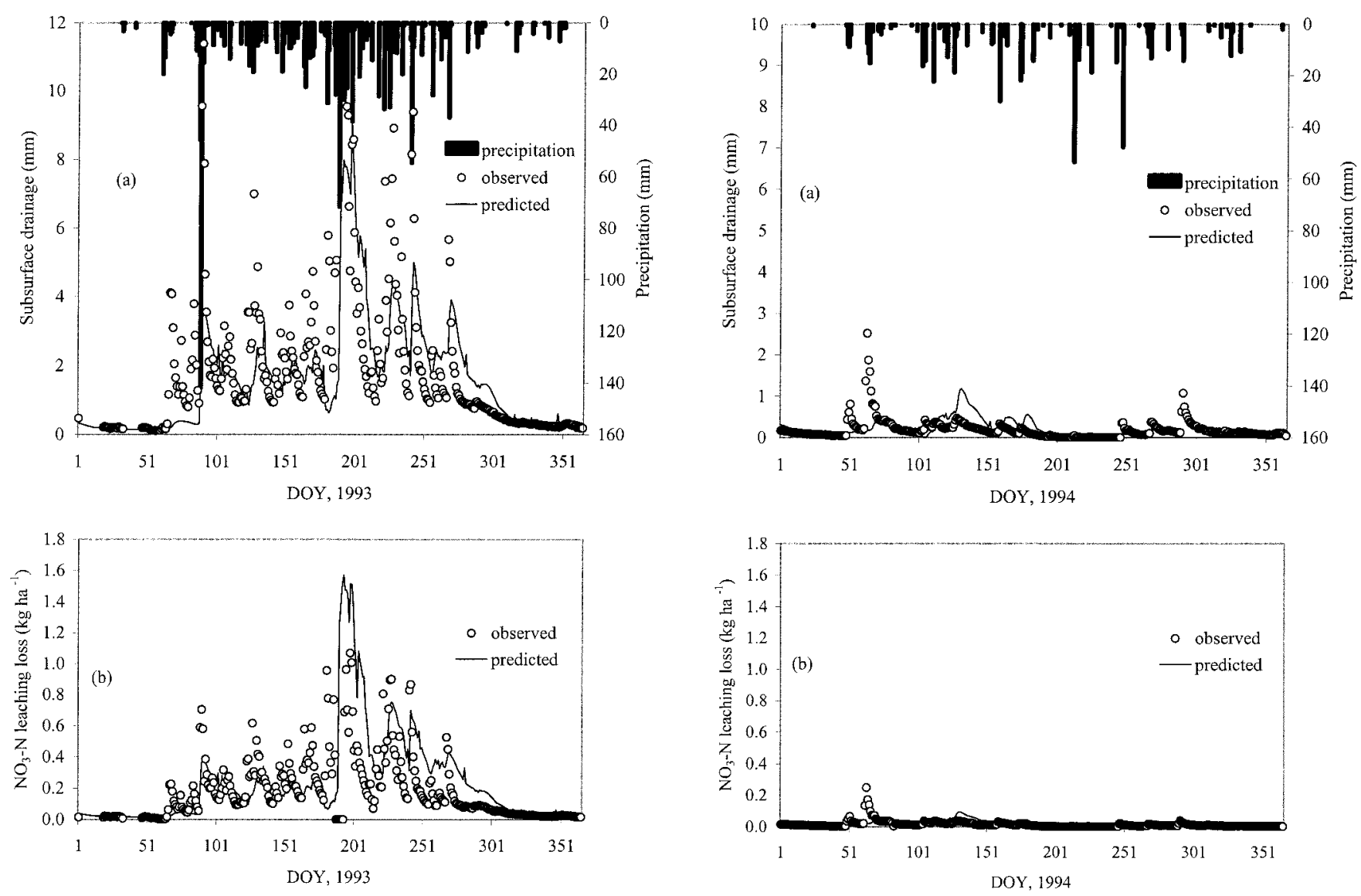

Fig. 2. Root Zone Water Quality Model with Windows interface simulations for $(a)$ subsurface drainage and $(b) \mathrm{NO}_{3}-\mathrm{N}$ losses in subsurface drainage water in relation to rainfall for 1993. DOY, day of year.

surface drainage flows during validation years showed that the annual volume of predicted subsurface drain flow was adequate for most of the years having rainfall closer to the normal precipitation. Similarly, the overall evaluation of the model for simulating $\mathrm{NO}_{3}-\mathrm{N}$ leaching losses in subsurface drainage water was acceptable. On the average, the $\% D$ between simulated and measured values for validation years was about $13 \%(26 \mathrm{vs} .23 \mathrm{~kg}$ $\mathrm{N} \mathrm{ha}^{-1}$ ) with other indicators $\mathrm{RMSE}=44.5 \%, R^{2}=$ $0.5, \mathrm{EF}=0.8$, and $\mathrm{CRM}=-0.1$ (Table 4). Some discrepancies exist in simulations of $\mathrm{NO}_{3}-\mathrm{N}$ leaching losses, which could be due to macropore flow during heavy rainfall events before and after the crop harvest (Fig. 1 and 3). The macropore option of the model was not invoked in this study because of lack of information on macroporosity. Moreover, this field was managed by the farmer, and the best estimate of $\mathrm{N}$-application rate provided by the farmer at the rate of $90 \mathrm{~kg} \mathrm{~N}^{-1}$ was used during simulations, which might have affected the nitrate leaching loss simulations.

Flow-weighted average nitrate concentrations (FWANC) are commonly reported as better indicators for evaluating chemical loads (Jaynes et al., 1999). The model overpredicted FWANC in 1993 and 1994 because of a prediction of large $\mathrm{NO}_{3}-\mathrm{N}$ losses and drainage for these years, and underpredicted FWANC for the other

Fig. 3. Root Zone Water Quality Model with Windows interface simulations for $(a)$ subsurface drainage and $(b) \mathrm{NO}_{3}-\mathrm{N}$ losses in subsurface drainage water in relation to rainfall for 1994. DOY, day of year.

years. The overall model simulations of FWANC, however, were within $5 \%$ of the observed values when averaged across the validation years (1993-1997) (Table 4) showing the $\mathrm{RMSE}=29.9 \%, R^{2}=0.3, \mathrm{EF}=-3.8$, and $\mathrm{CRM}=0$. The low values of $R^{2}$ and EF showed a lack of correlation between the two simulated results and observed data. The computations of FWANC were affected by the accuracy in predictions of subsurface drain flow and $\mathrm{NO}_{3}-\mathrm{N}$ losses. The errors in simulation of subsurface drain flow and $\mathrm{NO}_{3}-\mathrm{N}$ losses in subsurface drain flow also become compounded for FWANC computations because a lower value of subsurface drain flow (denominator) can result in a higher FWANC value.

Predictions of corn grain yields were satisfactory because the average predicted grain yields were in close agreement with the reported measured grain yield data for Iowa conditions by Jaynes and Miller (1999), Bakhsh et al. (2001), and Hanson et al. (1999). On average, the $\% D$ between simulated and reported measured grain yield was $<10 \%$ for corn ( 9447 vs. $8815 \mathrm{~kg} \mathrm{ha}^{-1}$ ) for the validation years. The model overpredicted the soybean yields by $20 \%$ (2889 vs. $2388 \mathrm{~kg} \mathrm{ha}^{-1}$ ) (Table 4). The timing of water and $\mathrm{N}$ uptake has been reported to be a very important factor in crop model simulations (Hanson et al., 1999). These errors could be due to the delicate balance among water, $\mathrm{N}$ uptake, and crop 

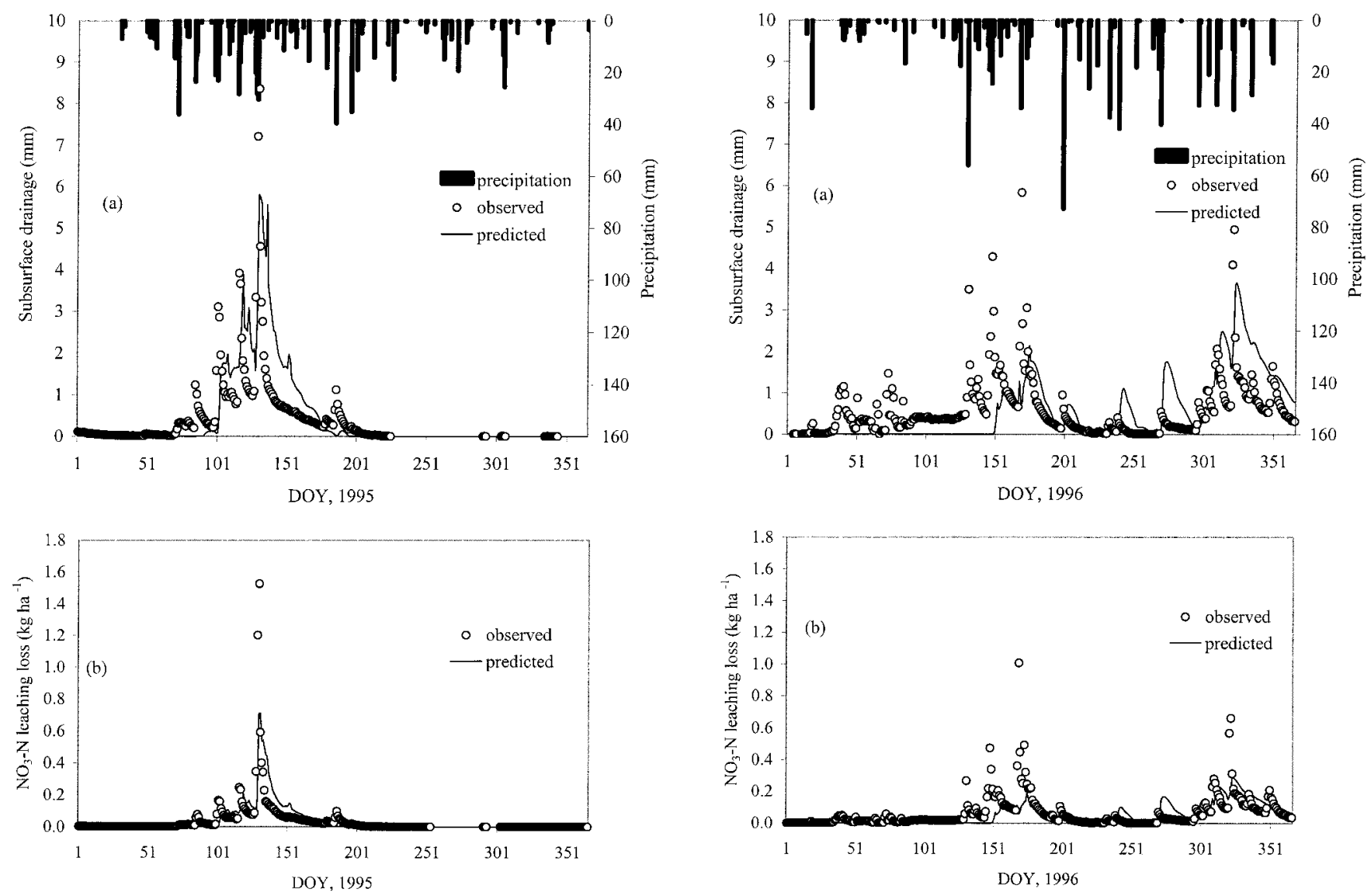

Fig. 4. Root Zone Water Quality Model with Windows interface simulations for $(a)$ subsurface drainage and $(b) \mathrm{NO}_{3}-\mathrm{N}$ losses in subsurface drainage water in relation to rainfall for 1995 . DOY, day of year.

growth processes. The simulation of soybean growth processes seems to be more sensitive to climate because soybean does not receive any fertilizer and its growth is mainly driven by climatic parameters. The algorithms, however, dealing with $\mathrm{N}_{2}$ fixation and $\mathrm{N}$-uptake processes, may need further refinements.

\section{Nitrogen-Scenario Simulations}

After calibrating and testing the model, different $\mathrm{N}$-scenario simulations were made using a single run from 1992 through 1997. Rates of applied N ranged from 0 to $180 \mathrm{~kg} \mathrm{ha}^{-1}$ at $30 \mathrm{~kg} \mathrm{ha}^{-1}$ increments in the corn phase of production. Corn grain yield response function varied slightly from year to year because of rainfall variability. With no $\mathrm{N}$ application, the predicted corn grain yield varied from $3546 \mathrm{~kg} \mathrm{ha}^{-1}$ for 1993 (Fig. 7) to $6170 \mathrm{~kg} \mathrm{ha}^{-1}$ for 1997 (Fig. 8). The $\mathrm{N}$-application rate was increased to $30 \mathrm{~kg} \mathrm{ha}^{-1}$, which resulted in a $67 \%$ increase in corn yield for 1993 , a $23 \%$ increase in 1995, and a 30\% increase for 1997. Similarly, doubling the $\mathrm{N}$-application rate from 30 to $60 \mathrm{~kg} \mathrm{ha}^{-1}$ resulted in a $20 \%$ increase in yield for 1993 , a $31 \%$ increase for 1995 , and a $24 \%$ increase for 1997 . Increasing the $\mathrm{N}$-application rate from 60 to $90 \mathrm{~kg} \mathrm{ha}^{-1}$ increased corn grain yield for 1993 (Fig. 7), decreased the yield for 1995, and made a slight increase for 1997 (Fig. 8). The

Fig. 5. Root Zone Water Quality Model with Windows interface simulations for $(a)$ subsurface drainage and $(b) \mathrm{NO}_{3}-\mathrm{N}$ losses in subsurface drainage water in relation to rainfall for 1996. DOY, day of year.

corn grain yield response function reached a plateau when $\mathrm{N}$-application rates exceeded $90 \mathrm{~kg} \mathrm{ha}^{-1}$ in 1993 and $60 \mathrm{~kg} \mathrm{ha}^{-1}$ in 1995 and 1997. The best scenario simulations were observed for 1997, when doubling the $\mathrm{N}$-application rate from 30 to $60 \mathrm{~kg} \mathrm{ha}^{-1}$ increased the corn grain yield by $24 \%$ but reduced the nitrate leaching losses by $3 \%$.

When $\mathrm{N}$-application rates were applied at rates exceeding those needed for optimum yield, $\mathrm{NO}_{3}-\mathrm{N}$ drainage losses increased (Fig. 7 and 8). These simulations showed that leaching losses of $\mathrm{NO}_{3}-\mathrm{N}$ in subsurface drainage water were affected by corn yield response to applied $\mathrm{N}$, as well as variability in precipitation from year to year (Hatfield et al., 2000). Andraski et al. (2000), studying four cropping-manure management systems at Arlington, WI, reported that total $\mathrm{NO}_{3}-\mathrm{N}$ leached within an 18-mo study period ranged from 3 to $88 \mathrm{~kg} \mathrm{ha}^{-1}$, depending on crop and manure management systems, $\mathrm{N}$-fertilizer rate, amount of water drainage, and time of drainage event relative to treatment establishment.

On average, these scenarios showed that when up to $60 \mathrm{~kg} \mathrm{~N}$ fertilizer ha ${ }^{-1}$ was used, each kilogram of $\mathrm{N}$ application resulted in an increase of $59 \mathrm{~kg} \mathrm{ha}^{-1}$ corn grain yield. The increase in $\mathrm{N}$-application rate from 60 to $90 \mathrm{~kg} \mathrm{ha}^{-1}$ resulted in only a $6 \%$ increase in corn 

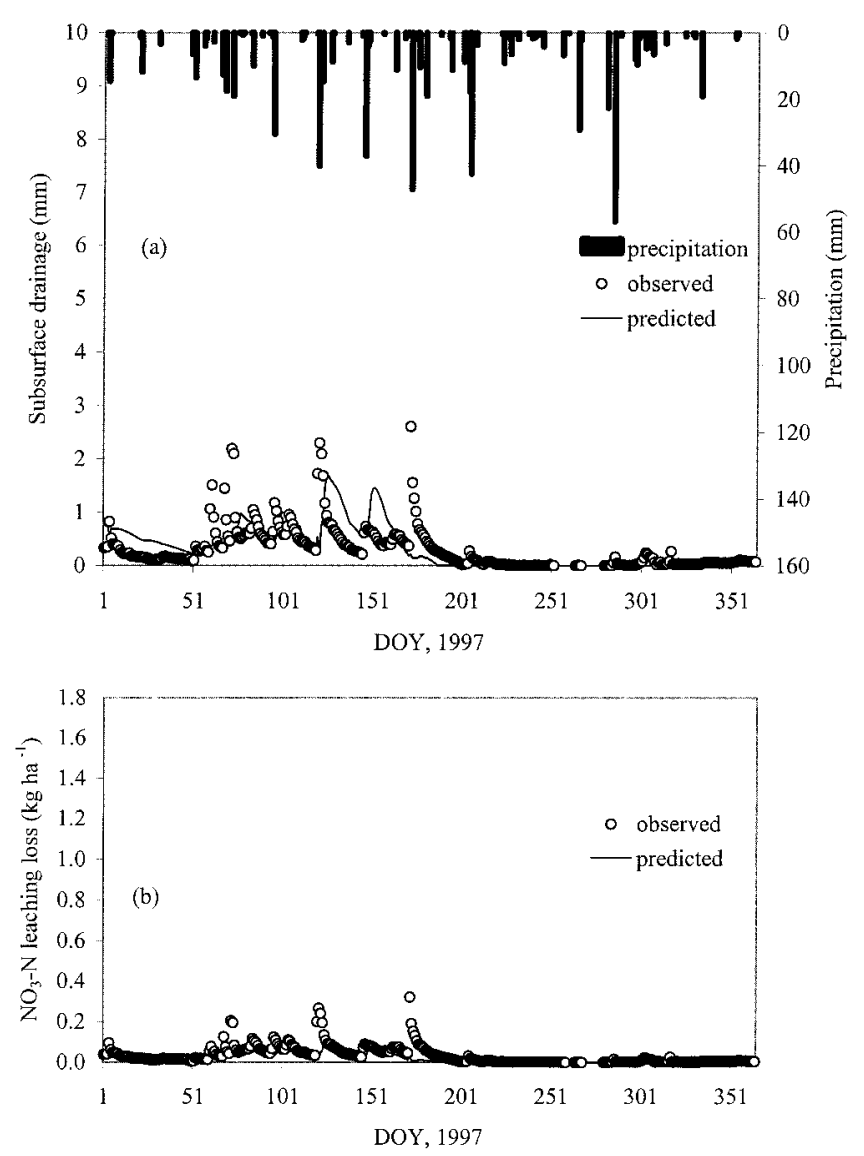

Fig. 6. Root Zone Water Quality Model with Windows interface simulations for $(a)$ subsurface drainage and $(b) \mathrm{NO}_{3}-\mathrm{N}$ losses in subsurface drainage water in relation to rainfall for 1997.

grain yield, and $14 \%$ increase in nitrate leaching losses. Further increases in the $\mathrm{N}$-application rate did not increase the corn grain yield for any of the remaining years, but each addition of $30 \mathrm{~kg} \mathrm{~N} \mathrm{ha}^{-1}$ increased nitrate leaching losses by 15 to $16 \%$. The fraction of applied $\mathrm{N}$ lost with subsurface drainage water varied with $\mathrm{N}$-application rates. On average, $25 \mathrm{~kg} \mathrm{~N}$ ha $^{-1}$ was leached in subsurface drainage flow with no $\mathrm{N}$ application, and this loss increased to $54 \mathrm{~kg} \mathrm{~N} \mathrm{ha}^{-1}$ at $180 \mathrm{~kg}$ $\mathrm{N}$ ha $^{-1}$ (Fig. 8). On the basis of different $\mathrm{N}$-scenario simulations, the fraction of applied $\mathrm{N}$ lost in subsurface drainage water ranged from 7 to $16 \%$ when the $\mathrm{N}$-application rate varied from 30 to $180 \mathrm{~kg} \mathrm{ha}^{-1}$ after accounting for the $\mathrm{NO}_{3}-\mathrm{N}$ losses with no $\mathrm{N}$-fertilizer application.

Baker and Timmons (1994) at a nearby site in central Iowa on the Clarion-Nicollet-Webster Soil association showed that fertilizer accounted for $17 \%$ of the total $\mathrm{NO}_{3}-\mathrm{N}$ leaching loss in the first year following subsurface banding of urea ammonium nitrate (UAN) solution. In the second and third year after fertilizer application, fertilizer $\mathrm{N}$ (applied in Year 1 and remineralized in Years 2 and 3) accounted for 25 and $7 \%$ of the $\mathrm{NO}_{3}-\mathrm{N}$ leaching losses, respectively. Cambardella et al. (1999), in data collected from the Walnut Creek watershed, reported that fertilizer $\mathrm{N}$ directly accounted for $<25 \%$ of the $\mathrm{NO}_{3}-\mathrm{N}$ lost to subsurface drainage water in the year it was applied. Jaynes et al. (1999) reported that
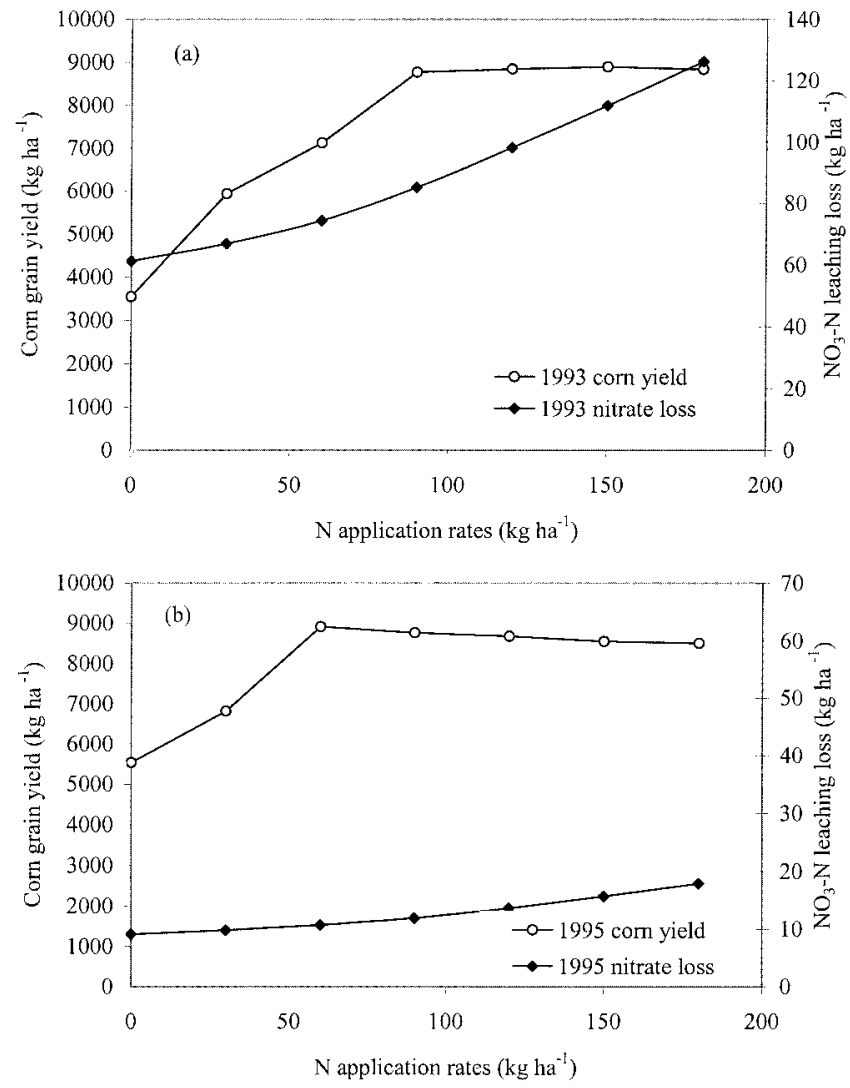

Fig. 7. Root Zone Water Quality Model with Windows interface scenario simulations for corn yields and nitrate leaching loss with subsurface drainage for $(a) 1993$ and $(b) 1995$.

$\mathrm{NO}_{3}-\mathrm{N}$ drainage loss varied from 10 to $50 \%$ of the applied $\mathrm{N}$ for the dry and wet year, respectively. They further emphasized that care must be taken to interpret the nitrate drainage loss in terms of the applied fertilizer rates because it is not the only source contributing to the loss. Randall and Iragavarapu (1995) also found from their 11-yr study conducted in Minnesota that 20 to $21 \%$ of the fertilizer applied in a given year was lost to tile drainage with both conventional and no-tillage systems. In general, for maize, crop uptake can remove $50 \%$ of the applied $\mathrm{N}$, and the remaining $50 \%$ can be divided approximately between leaching and denitrification (Allison, 1966; Gentry et al., 1998). Patni et al. (1996) found $\mathrm{N}$ loss to range from 10 to $39 \mathrm{~kg} \mathrm{~N} \mathrm{ha}^{-1} \mathrm{yr}^{-1}$ under conventional tillage on maize fields in Ontario (7-30\% of applied fertilizer), with loss primarily a function of precipitation amount during the dormant season. A simulation study conducted in Minnesota by Davis et al. (2000) predicted annual average $\mathrm{NO}_{3}-\mathrm{N}$ loss through subsurface drains $\left(44.6 \mathrm{~kg} \mathrm{ha}^{-1}\right)$ to be about $22.9 \%$ of the applied N. The RZWQM simulation results were in close agreement with these earlier studies, suggesting that the model has the potential to simulate the impact of $\mathrm{N}$-application rates on corn grain yields and $\mathrm{NO}_{3}-\mathrm{N}$ leaching losses in subsurface drainage water.

\section{CONCLUSIONS}

Six years (1992-1997) of field-measured data from a farmer's field, located in the Walnut Creek watershed, 

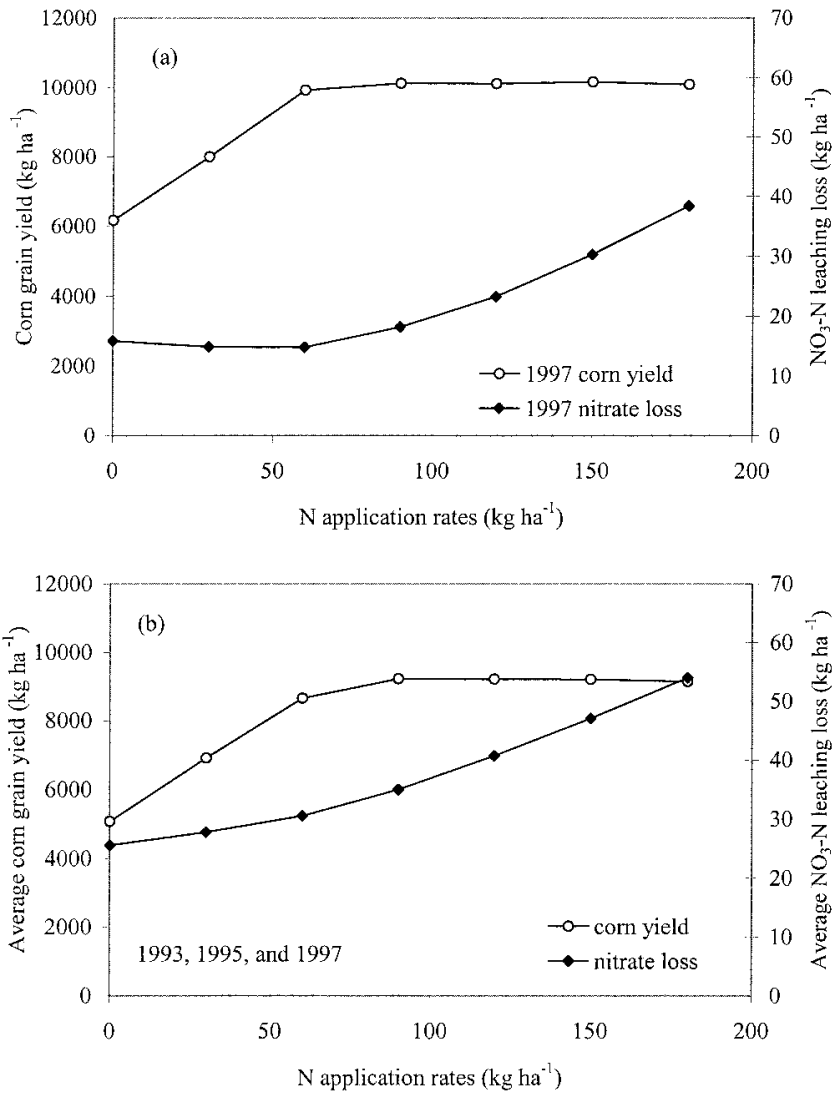

Fig. 8. Root Zone Water Quality Model with Windows interface scenario simulations for corn yields and nitrate leaching losses with subsurface drainage flows for $(a) 1997$ and $(b)$ 1993, 1995, and 1997.

were used to calibrate and evaluate the improved version of the RZWQM model. The measured data included subsurface drainage, $\mathrm{NO}_{3}-\mathrm{N}$ concentrations and losses with subsurface drainage water, and corn and soybean yields. The model was calibrated for hydrologic, nutrient, and plant components sequentially with 1992 data, and was validated with data from 1993 to 1997. The model evaluation criteria were based on statistical measures on $\% D$, RMSE, $R^{2}, \mathrm{EF}$, and CRM in addition to graphical comparison between the observed and predicted daily subsurface drainage and $\mathrm{NO}_{3}-\mathrm{N}$ loss with subsurface drainage water. The model simulations of drainage volumes, nitrate losses with subsurface drainage water, and corn yields were found to be in close agreement with the measured data. The estimation of nitrate loss with subsurface drainage water as a fraction of the applied $\mathrm{N}$, however, is a complex phenomenon because the applied $\mathrm{N}$ and the year of application are not the only factors contributing to this loss. Therefore, the validated model was used to simulate the impact of $\mathrm{N}$-application scenarios on the nitrate losses with subsurface drainage water and corn yields. The simulation results showed that 6 to $17 \%$ of the applied $\mathrm{N}$ contributed to the nitrate loss with drainage after accounting for the nitrate loss with drainage water when no $\mathrm{N}$ was applied. The model, however, overpredicted soybean yields, which may require further refinements in the $\mathrm{N}$-cycling algorithm in relation to $\mathrm{N}_{2}$ fixation and plant N-uptake processes.

\section{REFERENCES}

Ahuja, L.R., K.W. Rojas, J.D. Hanson, M.J. Shaffer, and L. Ma (ed.) 2000. Root zone water quality model. Water Resources Publ., Highlands Ranch, CO.

Allison, F.E. 1966. The fate of nitrogen applied to soils. Adv. Agron. 18:219-258.

Andraski, T.W., L.G. Bundy, and K.R. Brye. 2000. Crop management and corn nitrogen rate effects on nitrate leaching. J. Environ. Qual. 29:1095-1103.

Baker, J.L., and D.R. Timmons. 1994. Fertilizer management effects on leaching of labeled nitrogen for no-till corn in field lysimeters. J. Environ. Qual. 23:305-310.

Bakhsh, A., D.B. Jaynes, T.S. Colvin, and R.S. Kanwar. 2000a. Spatiotemporal analysis of yield variability for a corn-soybean field in Iowa. Trans. ASAE 43:31-38.

Bakhsh, A., R.S. Kanwar, D.B. Jaynes, T.S. Colvin, and L.R. Ahuja. 2000b. Prediction of $\mathrm{NO}_{3}-\mathrm{N}$ losses with subsurface drainage water from manured and UAN-fertilized plots using GLEAMS. Trans. ASAE 43:69-77.

Bakhsh, A., R.S. Kanwar, D.B. Jaynes, T.S. Colvin, and L.R. Ahuja. 2001. Simulating effects of variable nitrogen application rates on corn yields and $\mathrm{NO}_{3}-\mathrm{N}$ losses in subsurface drain water. Trans. ASAE 44:269-276.

Cambardella, C.A., T.B. Moorman, D.B. Jaynes, J.L. Hatfield, T.B. Parkin, W.W. Simpkins, and D.L. Karlen. 1999. Water quality in Walnut Creek watershed: Nitrate-nitrogen in soils, subsurface drainage water, and shallow groundwater. J. Environ. Qual. 28: 25-34.

Davis, D.M., P.H. Gowda, D.J. Mulla, and G.W. Randall. 2000. Modeling nitrate nitrogen leaching in response to nitrogen fertilizer rate and tile drain depth or spacing for southern Minnesota, USA. J. Environ. Qual. 29:1568-1581.

Gentry, L.E., M.B. David, K.M. Smith, and D.A. Kovaic. 1998. Nitrogen cycling and tile drainage nitrate loss in a corn/soybean watershed. Agric. Ecosyst. Environ. 68:85-97.

Ghidey, F., E.E. Alberts, and N.R. Kitchen. 1999. Evaluation of the Root Zone Water Quality Model using field measured data from the Missouri MSEA. Agron. J. 91:183-192.

Hanson, J.D., K.W. Rojas, and M.J. Shaffer. 1999. Calibrating the Root Zone Water Quality Model. Agron. J. 91:171-177.

Hatfield, J.L., D.B. Jaynes, M.R. Burkat, C.A. Cambardella, T.B. Moorman, J.H. Prueger, and M.A. Smith. 1999. Water quality in Walnut Creek watershed: Setting and farming practices. J. Environ. Qual. 28:11-24.

Hatfield, J.L., D.B. Jaynes, and J.H. Prueger. 1998. Environmental impacts of agricultural drainage in the Midwest. p. 28-35. In Drainage in the 21st Century: Food production and the environment. Proc. of the 7th Annual Drainage Symp., Orlando, FL. 8-10 Mar. 1998. ASAE, St. Joseph, MI.

Hatfield, J.L., S.A. McCaslin, and J.H. Prueger. 2000. Crop production BMP effectiveness and prediction of water quality improvements. p. 205-223. In Proc. of TMDL Science Issues Conf., St. Louis, MO. 4-7 March 2001. ASAE, St. Joseph, MI.

Jaynes, D.B., J.L. Hatfield, and D.W. Meek. 1999. Water quality in Walnut Creek watershed: Herbicides and nitrate in surface waters. J. Environ. Qual. 28:45-59.

Jaynes, D.B., and J.G. Miller. 1999. Evaluation of the Root Zone Water Quality Model using field measured data from the Iowa MSEA. Agron. J. 91:192-200.

Kanwar, R.S., D. Bjorneberg, and D. Baker. 1999. An automated system for monitoring the quality and quantity of subsurface drain flow. J. Agric. Eng. Res. 73:123-129.

Kanwar, R.S., R.M. Cruse, M. Ghaffarzadeh, K. Pecinovsky, D.L. Karlen, and C.A. Cambardella. 1998. Alternative cropping systems to improve the quality of shallow groundwater. p. 538-543. In Drainage in the 21st Century: Food production and the environment. Proc. of the 7th Annual Drainage Symp., Orlando, FL. 8-10 Mar. 1998. ASAE, St. Joseph, MI.

Knisel, W.G., and E. Turtola. 2000. GLEAMS model application on a heavy clay soil in Finland. Agric. Water Manage. 43:285-309.

Landa, F.M., N.R. Fausey, S.E. Nokes, and J.D. Hanson. 1999. Plant production model evaluation for the Root Zone Water Quality Model (RZWQM3.2) in Ohio. Agron. J. 91:220-227. 
Loague, K., and D.L. Corwin. 1996. Uncertainty in regional-scale assessments of non-point source pollutants. p. 131-152. In Applications of GIS to the modeling of non-point source pollutants in the vadose zone. SSSA Spec. Publ. No. 48. SSSA, Madison, WI.

Loague, K., and R.E. Green. 1991. Statistical and graphical methods for evaluating solute transport models: Overview and application. J. Contam. Hydrol. 7:51-73.

Ma, L., L.R. Ahuja, J.C. Ascough, II, M.J. Shaffer, K.W. Rojas, R.W. Malone, and M.R. Cameira. 2000. Integrating system modeling with field research in agriculture: Applications of the Root Zone Water Quality Model (RZWQM). Adv. Agron. 71:233-292.

Ma, L., M.J. Shaffer, J.K. Boyd, R. Waskom, L.R. Ahuja, K.W. Rojas, and C. Xu. 1998. Manure management in an irrigated silage corn field: Experiment and modeling. Soil Sci. Soc. Am. J. 62:1006-1017.

Martin, D.L., and D.G. Watts. 1999. Evaluation of the Root Zone Water Quality Model for conditions in central Nebraska. Agron. J. 91:201-211.

Nash, J.E., and J.E. Sutcliffe. 1970. River flow forecasting through conceptual models. Part 1-A: Discussion of principles. J. Hydrol. (Amsterdam) 10:282-290.

Patni, N.K., L. Masse, and P.Y. Jui. 1996. Tile effluent quality and chemical losses under conventional and no-tillage. 1. Flow and nitrate. Trans. ASAE 39:1665-1672.

Randall, G.W., and T.K. Iragavarapu. 1995. Impact of long-term tillage systems for continuous corn on nitrate leaching to tile drainage. J. Environ. Qual. 24:360-366.
Randall, G.W., and D.J. Mulla. 2001. Nitrate-N in surface waters as affected by climatic conditions and agricultural practices. J. Environ. Qual. 30:337-344.

Rejesus, R.M., and R.H. Hornbaker. 1999. Economic and environmental evaluation of alternative pollution-reducing nitrogen management practices in central Illinois. Agric. Ecosyst. Environ. 75: 41-53.

Saleh, A., J.G. Arnold, P.W. Gassman, L.M. Hauck, W.D. Rosenthal, J.R. Williams, and A.M.S. McFarland. 2000. Application of SWAT for the Upper North Bosque River Watershed. Trans. ASAE 43: 1077-1087.

Shirmohammadi, A., B. Ulen, L.F. Bergstorm, and W.G. Knisel. 1998. Simulation of nitrogen and phosphorus leaching in a structured soil using GLEAMS and a new submodel, PARTLE. Trans. ASAE 41:353-360.

USDA. 1994. Primary characterization data, Boone County, IA. USDA-ARS, Soil Conserv. Serv., Soil Survey of Land, Natl. Soil Survey Center, Lincoln, NE.

Vinten, A.J.A., H. Frenkel, J. Shalhevet, and D.A. Elston. 1991. Calibration and validation of a modified steady-state model of crop response to saline water irrigation under conditions of transient root zone salinity. J. Contam. Hydrol. 7:123-144.

Wu, L., W. Chen, J.M. Baker, and J.A. Lamb. 1999. Evaluation of the Root Zone Water Quality Model using field measured data from a sandy soil. Agron. J. 91:177-182. 